\title{
INNOVATION PROCESSES IN THE SOCIAL SPACE OF THE ORGANIZATION
}

\author{
KATARZYNA SZCZEPAŃSKA-WosZCZYNA ${ }^{1}$ \\ The Academy of Business in Dabrowa Górnicza (Poland)
}

\begin{abstract}
Innovation is not only an economic mechanism, or a technical process. It is primarily a social phenomenon in which the motivation and participation of employees are determinants of success in the process. Hence, many authors emphasise the social dimension of innovation. The paper summarizes the conclusions of the studies conducted among employees from Polish companies on identification of "soft" determinants of innovation processes in the organization, such as human resources, innovative climate and culture conducive to innovation.

KEY WORDS: innovation, innovation processes, human resources, organizational development.
\end{abstract}

JEL CODES: M5, O31

DOI: http://dx.doi.org/10.15181/rfds.v14i3.878

\section{Introduction}

Research problem: The innovation process is the implementation of innovation in the social system of the organization. The process begins when a decision about introducing change is made in the company. This process depends on the attitudes of managers and employees to change. On the one hand, innovation is a real or potential threat for employees, violating the state of social balance and causing employees' resistance (the implementation of innovation is associated with uncertainty, risk taking, sounding out, experimenting and testing). At the same time, motivation, creative and innovative thinking of employees are essential for success in innovation processes. It is, therefore, important to create an innovative climate that supports innovation processes in the company. The findings indicate that even not very dynamic companies are able to strengthen their market position through innovation, if they are given appropriately broad importance, and entrepreneurs and managers are willing to take risks and be more active compared to competitors. A lot also depends on their management style and the atmosphere created in the company. The democratic style and atmosphere of intra-entrepreneurship are favourable to innovation.

The purpose of this paper is a research investigation of internal factors that determine the innovation processes in the organization, i.e. the elements of the innovative climate and organizational culture conducive to innovation.

The object of research - social determinants of innovation processes in the company.

Research methods: theoretical analysis of scientific literature, a direct survey (the instrument of data collection was questionnaires).

1 Katarzyna Szczepańska-Woszczyna - PhD, assistant professor, the Academy of Business in Dąbrowa Górnicza, Management Department. Scientific interests: managerial competencies, innovation, marketing

E-mail: kszczepanska@wsb.edu.pl

Tel.: +48601518 218 


\section{Company innovativeness and innovation processes}

\subsection{The concepts of innovation and innovativeness}

Innovation is any change, favorable by definition, in different areas of the organization activity, introducing progress compared to the existing state, developed in or outside the organization, being a response to the needs signaled or satisfying the needs previously unrevealed (Brown, Ulijn, 2004: 2; Lesaková, 2008: 8). It has the evolutionary character of improving existing things, assessed positively in the light of the criteria of the organization (Wojtowicz, Kozioł, 2012: 212). The basis for developing and implementing innovation is appropriate knowledge resources in the form of inventions, industrial designs, acquired licenses, proprietary copyright, know-how, formulas, etc. It can be assumed that the essence of innovation is knowledge and learning.

Innovativeness is the company's willingness and ability to seek, assimilate and develop new and improved products, services provided or technologies used (Janasz, Kozioł, 2007: 57), as well as the ability to efficiently allocate resources to shape the optimal configuration of competitive advantages within the specified time (Bielski, 2000: 87). Innovativeness determines the level and direction of the company development, indicating progress, growth and competitive advantage. Analyzing the definitions of innovativeness in the relevant literature it can be said that innovativeness is the ability to continuously create and implement innovations that are appreciated by customers due to their high level of modernity and competitiveness in a global scale (Skrzypek, 2011: 26). Innovativeness can arise from the assumptions adopted within individual functional areas of the company. Innovativeness and innovation are not identical concepts but they are closely related because innovativeness is often measured by means of innovations created and implemented and expenditure allocated by the company on activity in this area.

The overall innovativeness of the company is determined by its ability and willingness to absorb innovation, involvement in innovative processes and the ability to acquire resources and skills necessary to participate in these processes. The propensity for innovation is expressed in interest in changes. The ability to innovate means having sufficient resources and the internal structure that allows the creation of inventions and/or transforming them in innovations. The innovative ability of companies, the ability to transform all of its resources into real innovation and competitive advantage depends on its characteristics (size, structure, complexity, resources, firm's market orientation and presence of strategic, managerial and marketing changes, etc.), its contacts with the environment and the characteristics of the environment and in particular on education, knowledge of company employees and the qualifications and competence of managers (Bozic, Radas, 2009: 440; Balcerowicz, Wziątek-Kubiak, 2009: 17).

Many authors highlight the social dimension of innovation (Roth, 2009: 232; Labuda, 2008: 229; Kożusznik, 2010: 6). Innovation is not only an economic mechanism, or a technical process. It is primarily a social phenomenon. In their nature, innovations are a collective process that requires the gradual involvement of the increasing number of participants. Thus, motivation and participation of employees are determinants of success in the process.

\subsection{Innovation processes}

All innovations have no broader economic and/or social significance (for both their creators and users) until they are practically used by implementing them into production. The necessary condition for commercialization of each innovation is the existence of an appropriate sequence of events (actions), which is defined as the innovation process. The concept of the innovation process can be interpreted both in the narrow and broad sense. In the narrow sense, the innovation process is traditional control of the innovative process, already expanded by new elements, but proceeding in a routine manner (a decision to innovate at a higher level, information, implementation, adaptation of the system), within clearly defined borders. This concept, used in plural, refers to establishing a creative organization with innovative culture and means con- 
stantly renewed innovation processes, whose boundaries blur not only between successive innovations, but also between creativity (the sphere of ingenuity, idea) and innovation (the sphere of innovation) and whose long-term objective is to increase the innovation capacity of the organization system, to develop a learning organization, capable of adapting, collecting and using knowledge. In this perspective, innovation processes mean gaining autonomy, strategic advantage over the competition, acquiring unique traits and behaviors, changing the organizational culture. Innovation processes are also analyzed in micro and macro perspectives. In the micro perspective, patterns and generalizations are sought, concerning the inventive process, the triad of research, development, and implementation, as well as a response to a question about the advantage of supply over demand-based innovation stimulation, relationship of expenditure on research with their effects. The innovation process can also be seen from the point of view of the organization or groups or individuals operating in it. Changes in behavior of innovative processes participants lead to organizational development (redirecting the organization to one of the tracks of innovative strategies), and transferred to the growing circles of society, can trigger social change (Francik, 2003: 9-10, 47).

\section{Innovation processes in the social system of the organization}

The innovation process is the implementation of innovation in the social system of the organization (Figure 1). It consists of two stages: the stage of innovation development and dissemination stage. The beginning of the innovation process may be developing and collecting inventions (regardless of the place of their origin). The next steps include selecting one of the concepts, taking the decision on how to implement it, that is specific actions enabling the introduction of innovations in organizational reality. The innovation process begins in a specific organizational context that determines its course.

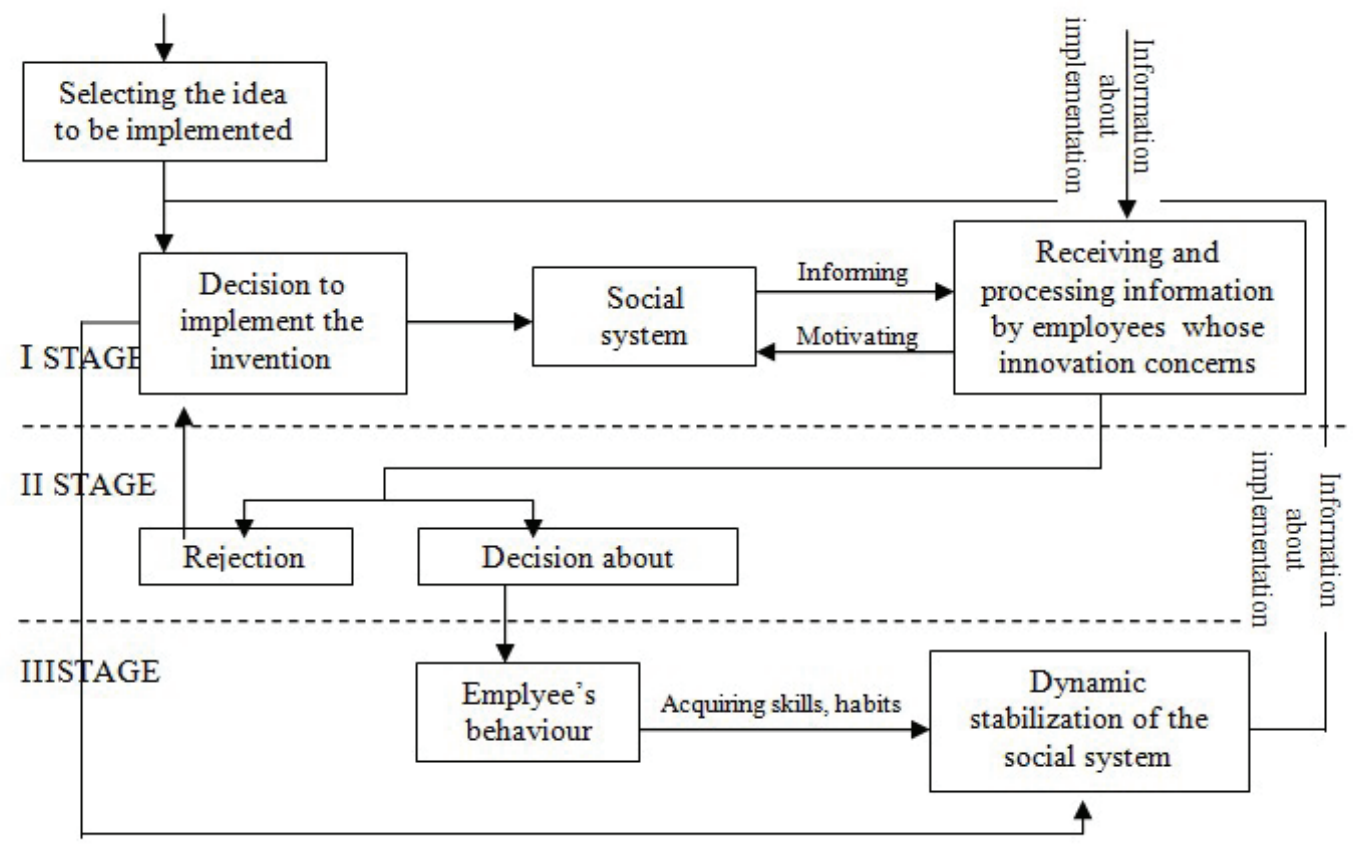

Figure 1. Stages of the innovation process

Source: Francik, Pocztowski, 1991: 30

The innovation process in the company begins when the decision about introducing change is made in the company. This process depends on the attitudes of managers and employees to change. Innovation is for employees a real or potential threat, violating the state of social balance and causing employees' resistance (the implementation of innovation is associated with uncertainty, risk taking, sounding out, experimenting and testing). Thus, the organization of the innovation process should aim to overcome such barriers and 
achieve the state of balance of the organization social system in the final stage. At the same time, in order to cope with the knowledge-based competition of a new type, it is necessary to search for synergistic effects of broadly understood innovation. It is essential, therefore, to have access to a variety of resources, especially intangible. This implies the need to care for the appropriate level of innovative behavior of employees. These, in turn, derive from innovation-oriented instruments, rules and management procedures. Innovation is understood as the ability to innovate, it requires respect for the individual, the perception of the employee not only as a means of conveying human capital, but primarily as the subject of the innovation process (Bal-Wozniak, 2013: 405-406). It should be emphasised that in managing the process of innovation implementation, flexibility of response to competitive challenges is significantly affected by access to innovative competence and, therefore, it is necessary to manage innovativeness as a process of shaping this competence referring them to people as current and potential participants in the innovation process. Equipping people with this competence is the process of strengthening their ability to actively participate in solving problems in the organization.

A subject of the innovation process - a human being - participates in the business processes in a dynamic way, depending on the current phase of the life cycle of the individual and the life cycle of an organization, in which he or she performs defined functions and plays professional and social roles. In order to optimally use the potential of activity and creativity of employees, it is necessary to take into account their objectives as participants in the processes that contribute to implementing business plans. These participants belong to specific groups of stakeholders; adopt certain attitudes and behavior based on their perception of their own anticipation in these processes. If it is positive, psychological barriers to their activity disappear.

Innovativeness perceived in terms of a subject is seen as a specific competence. According to the theory of competence (Boytazis, 1982: 97; Lévy-Leboyer, 1997: 19), it includes knowledge, skills, values, attitudes, and they are components of the company innovation potential, including a set of resources enabling it to achieve the innovation-related objectives. A category of competence (here as a component of innovation) is gradable, which means that through appropriate interaction (management, coordination) it may influence the change in its states (Bal-Wozniak, 2013: 407).

Four areas are crucial to effectively implement innovation: leadership behavior, management processes, people and skills, organizational culture and values (Loewe, Dominiquini, 2006: 24-25; Leiponen, 2005). On the basis of these areas, sustainable internal competence is built for innovation as a continuous process, not incidental, short-term effort (Figure 2).

A prerequisite for the effective team activity, whose task is creative, innovative problem solving, is the openness and willingness to share knowledge and experiences with others. This approach is partly due to personality determinants of team members, so organizational culture is also important here, which can effectively promote or inhibit cooperation, exchange of knowledge, experience and ideas. Open culture, promoting the participation of all team members in the creative process, is favorable to the activity and initiative of employees, while culture based on strong control is definitely not conducive to creativity and innovation. Cultures aimed at developing innovation and creating suitable conditions for doing so are characterized by dynamism, flexibility, fast adaptation to changing conditions, and non-stereotypical solutions. A key to the development of innovation in an organization is support, and encouragement for every employee to seek and discover unconventional, non-standard ways of achieving objectives and performing tasks. Thanks to the participation, an employee has greater responsibility, but also bigger motivation (he / she is not only the "robot", an individual carrying out a superior's order). However, it is necessary to create an environment giving a sense of security, lack of fear, both of criticism and "theft" of the idea by co-workers, and a transparent incentive system taking into account the initiative of employees and rewarding for their active participation in the innovation process, while allowing and accepting impractical solutions, mistakes and risk associated with them. The efficient flow of information is also important- understanding the reasons for and benefits of the changes by all sides involved is necessary for their effective implementation. Personality of team managers, who initiate new projects, or give the "green light" to the initiatives submitted by employees, is also significant (Brouwer, 2002: 83-105; Schumpeter, 2002; Szczepańska-Woszczyna, 2014: 13). Excessive 
formalization and bureaucratization of processes, as well as extensive control structures are not conducive to innovation. They both delay the decision-making processes, and inhibit the creativity of employees (Fabrowska, 2010: 44-45; Loewe, Dominiquini, 2006: 26-28).

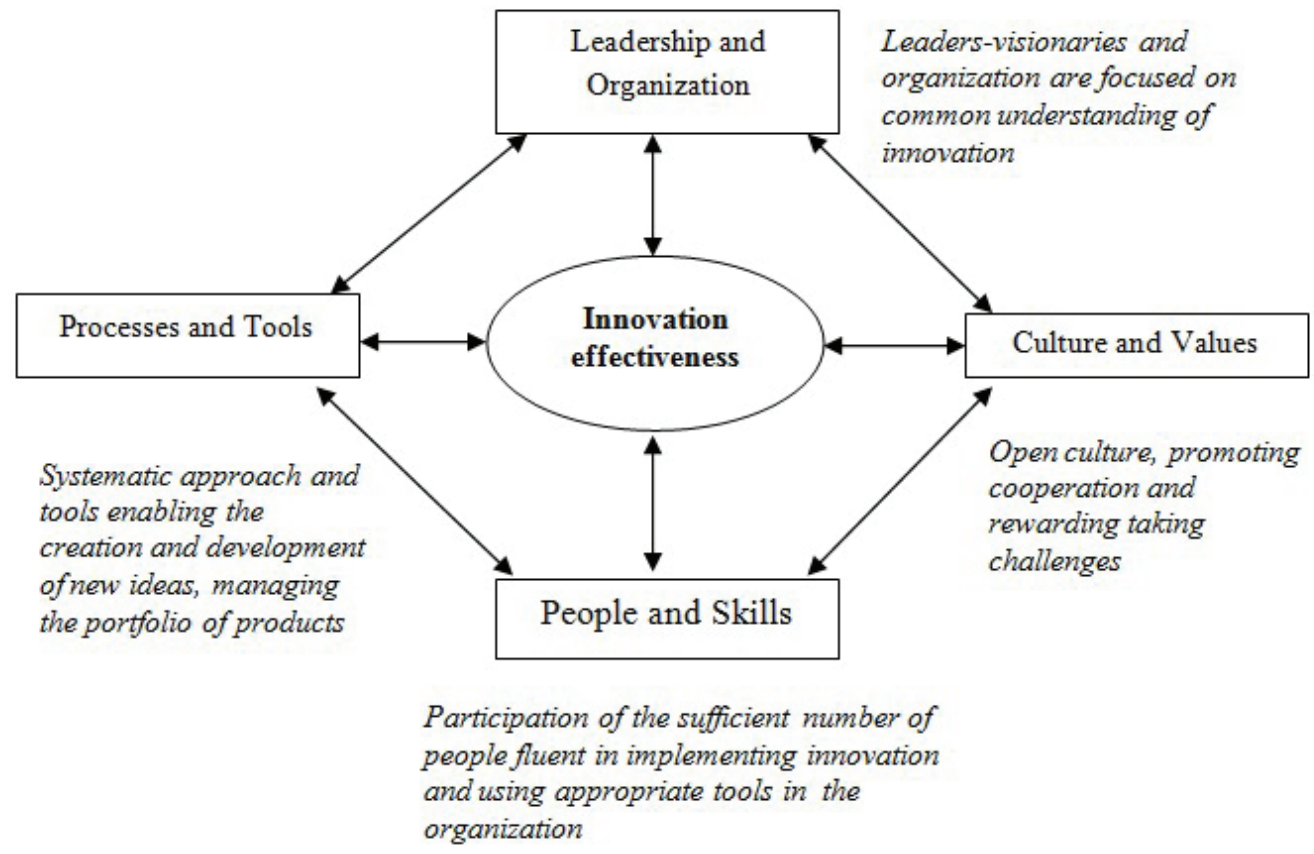

Figure 2. Key areas of a systemic innovation capability

Source: Loewe, Dominiquini, 2006: 26

The research findings show that even not very dynamic companies are able to strengthen their market position through innovation, if they are given appropriately broad importance, and entrepreneurs and managers are willing to take risks and be more active compared to competitors. A lot also depends on their management style and the atmosphere created in the company. The democratic style and atmosphere of intraentrepreneurship are favorable to innovation. Thanks to them, the process of creating innovation, regarded as a social process, becomes more efficient.

\section{Social determinants of innovation processes}

\subsection{Objectives and research sample}

The aim of the study was to investigate the internal determinants of innovation activity in the companies surveyed, in particular human resources, an innovative climate and culture favorable to innovation. The quantitative sample of analysing the internal determinants of innovation activity in companies contains 174 employees - representatives of companies located in the Province of Silesia in Poland. We eliminated the respondents who failed to answer at least 20 per cent of the questions. A total number of 152 usable questionnaires were received. Distribution of the sample is shown in Table 1.

The research was conducted by means of a direct survey. The instrument of data collection was questionnaires. A questionnaire consisting of 10 questions with a mixture of Likert-scale and closed-ended questions with one answer was developed. A five-point Likert scale was employed to gather responses, 5 indicating "maximum agreement" and 1 "no agreement". The survey was sample-based. Non-random sampling was applied and advantages and disadvantages specific to this method of sampling were considered. A small group of those surveyed does not authorize to make generalizations, but allows the identification of the spe- 
cific mechanisms and formulation of questions and conclusions. Tested on a larger sample, they will make it possible to formulate more documented and certain, useful theses on a larger scale. The data was collected in April and May 2014. The data was first analysed using basic statistical techniques. Data analysis was accomplished using IBM SPSS Statistics 21.

Table 1. Distribution of the sample (\%)

\begin{tabular}{|c|c|c|c|c|c|}
\hline \multicolumn{2}{|l|}{ Gender } & \multicolumn{2}{|l|}{ Age } & \multicolumn{2}{|l|}{ Seniority } \\
\hline \multirow[t]{2}{*}{ Woman } & \multirow[t]{2}{*}{65.0} & Below 25 years & 30.8 & Up to 5 years & 24.8 \\
\hline & & 25-30 years & 26.5 & $5-10$ years & 46.2 \\
\hline \multirow[t]{3}{*}{ Man } & \multirow[t]{3}{*}{35.0} & $31-40$ years & 31.6 & 11-20 years & 17.9 \\
\hline & & $41-50$ years & 9.4 & Over 20 years & 11.1 \\
\hline & & Over 50 years & 1.7 & & \\
\hline \multicolumn{2}{|l|}{ Position } & & & \multicolumn{2}{|l|}{ Company } \\
\hline $\begin{array}{l}\text { Non-managerial position (e.g. } \\
\text { a specialist) }\end{array}$ & 65.8 & $\begin{array}{l}\text { I manage a team of at } \\
\text { least ten people }\end{array}$ & 18.8 & $\begin{array}{l}\text { Micro company (up to } 9 \\
\text { people) }\end{array}$ & 18.8 \\
\hline Operational manager & 12.8 & $\begin{array}{l}\text { I manage a team of four- } \\
\text { nine people }\end{array}$ & 10.3 & $\begin{array}{l}\text { Small enterprise (from } 10 \\
\text { to } 50 \text { people) }\end{array}$ & 19.7 \\
\hline Middle manager & 15.4 & $\begin{array}{l}\text { I manage a team of two- } \\
\text { three people }\end{array}$ & 10.3 & $\begin{array}{l}\text { Medium-sized enterprise } \\
\text { (from } 51 \text { to } 250 \text { people) }\end{array}$ & 25.6 \\
\hline Senior manager & 6.0 & $\begin{array}{l}\text { I do not manage teams of } \\
\text { people }\end{array}$ & 60.7 & $\begin{array}{l}\text { Large enterprise (over } 250 \\
\text { people) }\end{array}$ & 35.0 \\
\hline
\end{tabular}

Source: own study

\subsection{Support for innovation processes}

Each innovation may be a threat to employees because it violates the current state of balance, which can lead to employees' reluctance to implement innovation and even boycott and sabotage change. Among the respondents, only $9 \%$ feel threatened by risks arising from the implementation of innovation in the company, fearing the change in the scope of their duties, redundancies, reorganization or new responsibilities. The majority (66.7 \%) were people employed in non-managerial positions). Almost every second respondent (44.7\%, of which $60.0 \%$ are people employed in non-managerial positions) felt the danger in a moderate degree, which indicates that the implementation of innovation in the company may violate balance felt by employees, therefore it requires neutralizing activities.

A key to the development of innovation in an organization is support and encouragement for every employee to seek and discover non-conventional, non-standard ways of achieving the objectives and performing tasks. $46.3 \%$ of the respondents believe that the organization supports the new ideas of employees (the opinion most often expressed by operational employees and senior managers $(50.0 \%$ of respondents in each group). Negative opinions were expressed by low-level (operational) managers $(40.0 \%)$. Senior managers did not rate the issue negatively. Therefore, a discrepancy can be observed in the assessment of employees and their superiors.

In the organizations studied there is a need for change and efforts are made to introduce it, the need to innovate is seen by all the employees of an organization. Management declares a positive attitude to innovate; regardless of the level they occupy in the structure, employees can propose new ideas and solutions that are further discussed, as long as they are part of a corporate strategy. Organizational culture is characterized by openness to the creation of new knowledge and its use in the innovation processes; managers are not afraid of change and encourage their subordinates to introduce it. However, some discrepancy can be observed in the assessment of the elements related to the innovation climate made by operational employees and managers. The assessment of the elements that affect the climate of innovative is presented in Figure 3. 


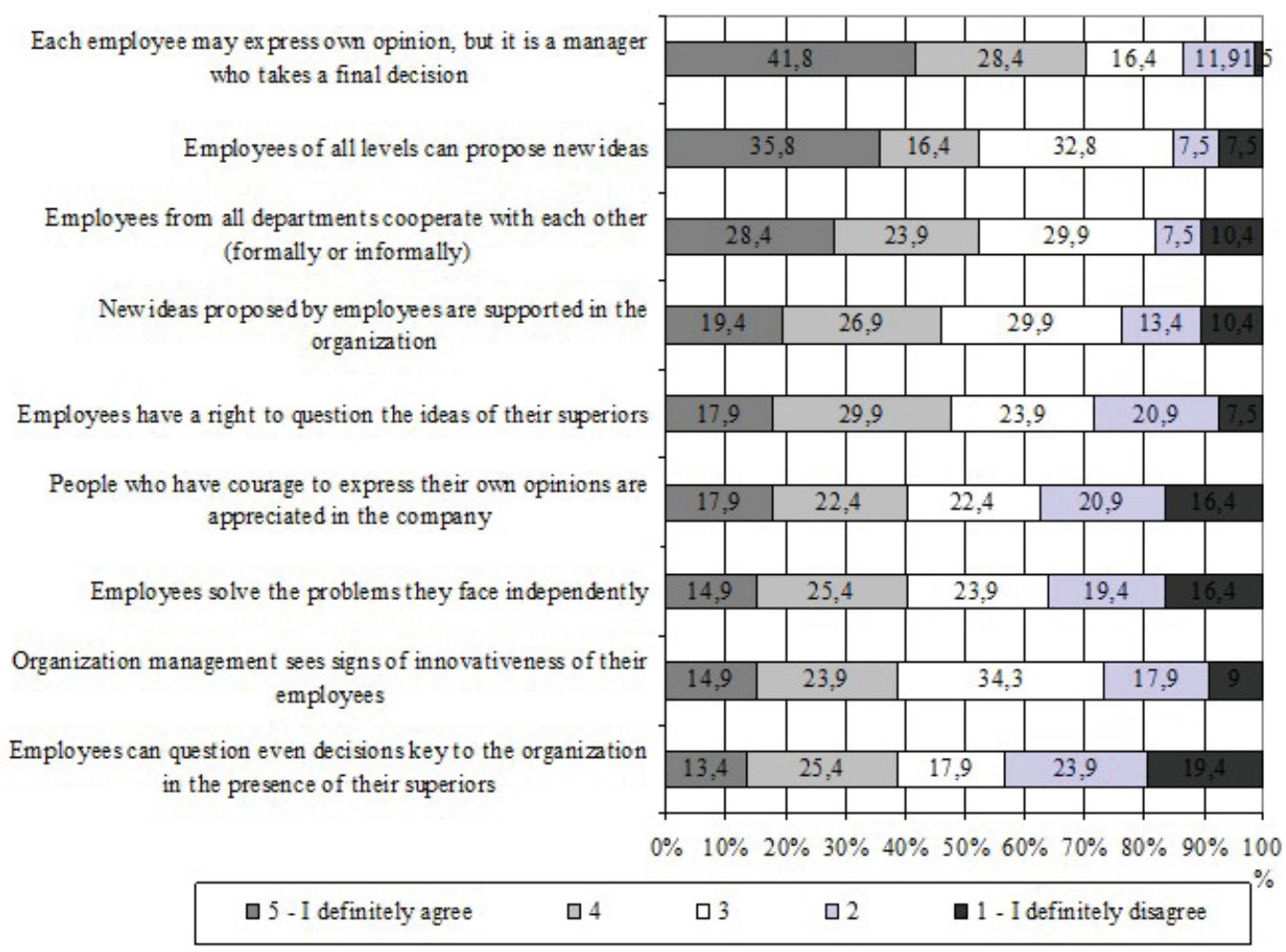

Figure 3. Elements of innovation climate

Source: own study

The comparison of companies that implement innovation and that do not shows that companies where innovative processes take place, new ideas of employees are noticed to a greater extent, managers are more open to their subordinates' opinions, they recognize and reward signs of innovation of their employees, there is a greater cooperation between employees from different organizational units (Fig. 4).

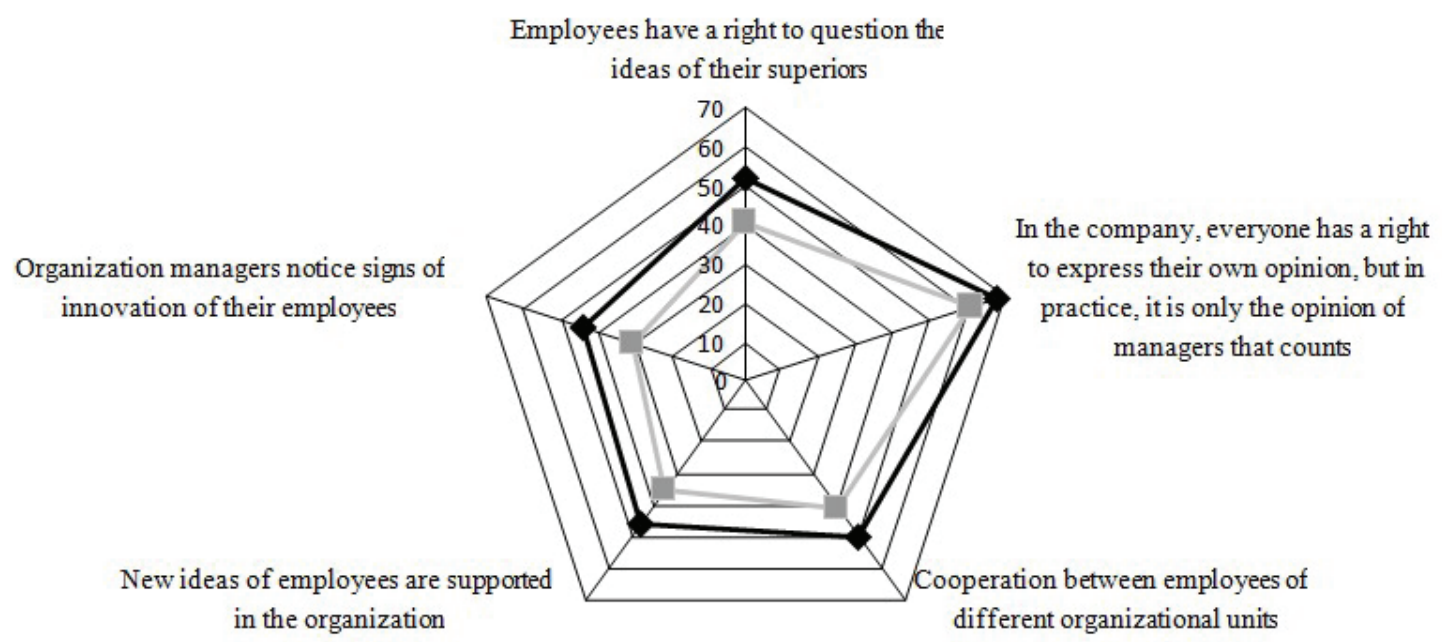
and that do not implement innovation

Source: own study 


\subsection{Barriers to innovation activity}

The element most frequently reported by the respondents that limits innovation processes is rather organizational and financial constraints: bureaucracy, high cost of credit and the lack of funds for the implementation of innovation. However, it should be noted that the problem could also be the reluctance of employees to propose ideas for improvement and completely new solutions (Figure 5). Every third respondent also mentioned too low qualifications of employees to implement innovation, however, significant differences can be observed in the assessment of the operational staff $(26.0 \%)$ and managers $(40.0 \%)$. It is, therefore, necessary to ensure organizational environment that gives you a sense of security, a lack of fears, both of criticism and the "theft" of the idea by co-workers, and the transparent incentive system that takes into account the employees' initiative and rewards employees for their active participation in the innovation process, while allowing and accepting impractical solution, mistakes and risk associated with them that appears.

The problem seems to be developing a strategy for the organization development, including, in particular, such elements that are related to its innovation activity, and then making the employees aware of it. However, it is not only about informing about innovation, but also about making employees aware of the purpose of this activity in the organization, their roles in the innovation process, as well as their ability to influence this process. Improving the flow of information on innovative activity is also significant.

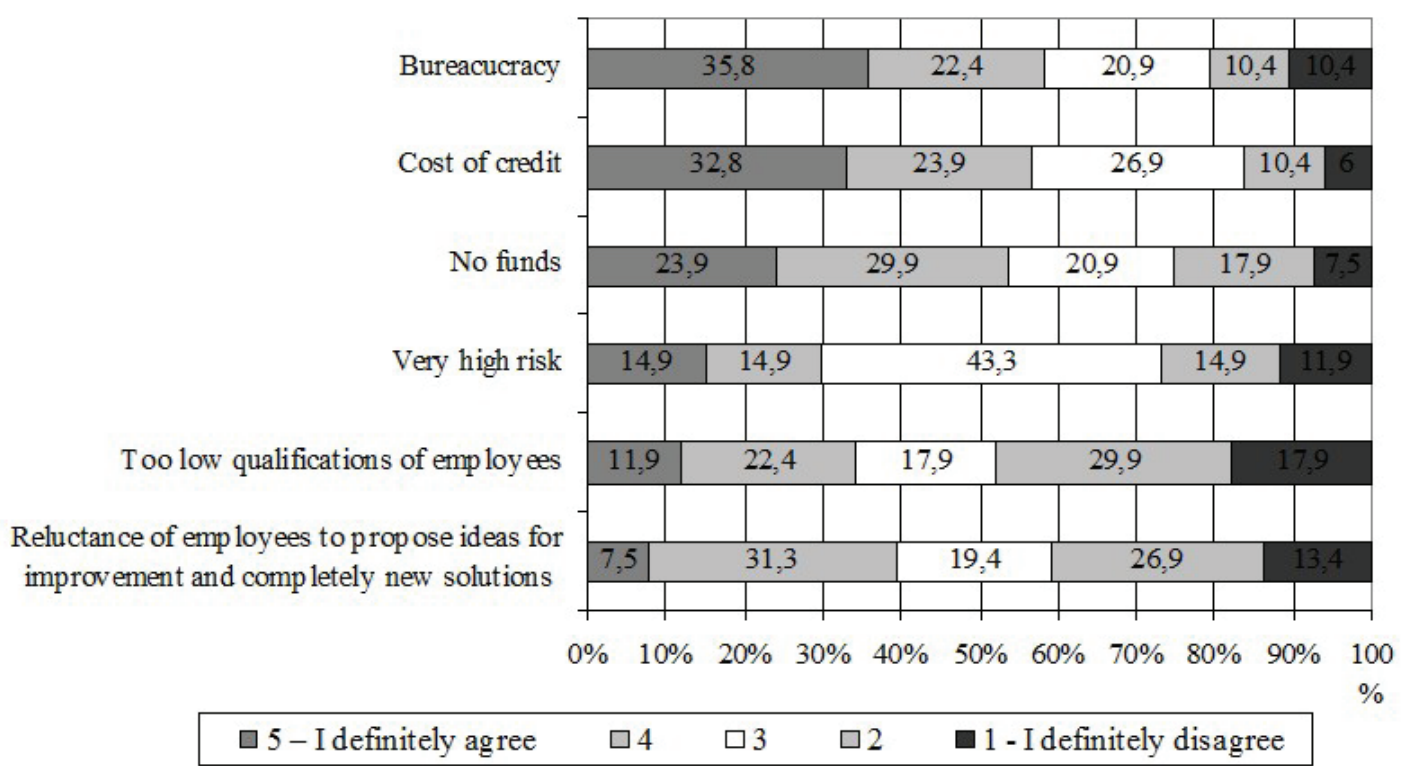

Figure 5. Barriers to innovation activity

Source: own study

\section{Conclusions}

Innovation has a social dimension, it is the result of a variety of interactions and relationships between individual actors and in order to be implemented, it must have social approval, because it changes paradigms, both in the ways of thinking, production, organization and management, as well as consumption. The key innovative resources directly affecting the innovation include human capital resource - human capital has a dual meaning here: it is a creator of new knowledge and a factor enabling adaptation and absorption of external knowledge. The importance of a human factor in the process of change, such as innovative processes, is due to the fact that organizations change through people - it is people who need to assimilate the change, take on new tasks and then develop them. Therefore, the problem of change needs to be considered from the perspective of people involved in the process. 
According to the research, the feeling of uncertainty associated with change during and after completing the innovation implementation process can lead to resistance of employees, including sabotaging change. The problem may also be a reluctance of employees to propose ideas for improvement and completely new solutions, resulting from the lack of a sense of security and fears, both of criticism and the "theft" of the idea by co-workers, a lack of confidence to the employer and no clear incentive system taking into account the employees' initiative and rewarding them for their active participation in the innovation process.

\section{References}

Balcerowicz, E., Wziątek-Kubiak, A. (2009). Determinanty rozwoju innowacyjności firmy w kontekśsie poziomu wyksztatcenia pracowników. CASE - Centrum Analiz Społeczno-Ekonomicznych. Warszawa.

Bal-Woźniak, T. (2013). O potrzebie wykorzystywania nowych form koordynacji współpracy w zarządzaniu innowacyjnością. Nierówności spoleczne a wzrost gospodarczy, Zeszyt, Nr. 30, Rzeszów: Uniwersytet Rzeszowski, Katedra Teorii Ekonomii i Stosunków Międzynarodowych.

Bielski, I. (2000). Przebieg i uwarunkowania procesów innowacyjnych. Bydgoszcz: Oficyna Wydawnicza Ośrodka Postępu Organizacyjnego Sp. z.o.o.

Boyzatis, R. (1982). The Competent Manager: A Model for Effective Performance. New York: John Wiley \& Sons.

Bozic, L., Radas, S. (2009). The antecedents of SME innovativeness in an emerging transition economy. Technovation, Vol. 29, p. 438-450.

Brouwer, M. T. (2002). Weber, Schumpeter, and Knight on Entrepreneurship and Economic Development. Journal of Evolutionary Economics, Vol. 12, No. 1-2, p. 83-105.

Brown, T. E., Ulijn, J. M. (eds.) (2004). Innovation, entrepreneurship and culture: The interaction between technology, progress and economic growth. Northampton, MA: Edward Elgar.

Fabrowska, P. (2010). Kreatywność i innowacyjność przedsiębiorstwa a kultura organizacyjna firmy. Doradca Zawodowy, Kwartalnik, No. 13.

Francik, A. (2003). Sterowanie procesami innowacyjnymi w organizacji. Kraków: Akademia Ekonomiczna.

Francik, A., Pocztowski, A. (1991). Procesy innowacyjne. Kraków: Akademia Ekonomiczna.

Janasz, W., Kozioł, K. (2007). Determinanty dziatalności innowacyjnej przedsiębiorstw. Warszawa: PWE.

Kożusznik, B. (2010). Psychologiczne uwarunkowania innowacyjności. Chowanna, Vol. 2(35). Wyd. UŚ, Katowice.

Labuda, G. (2008). Rozważania nad teoria i historia cywilizacji. Wyd. Poznańskie, Poznań.

Leiponen, A. (2005). Skills and innovation. International Journal of Industrial Organization, No. 23, p. 303-323

Lesaková, L. (2008). Inovácie - imanentná súčast' podnikania v globálnom ekonomickom prostredí'. Determinanty inovačnej aktivity malých a stredných podnikov v SR. Banská Bystrica, Ekonomická fakulta UMB, s. 7-20.

Lévy-Leboyer, C. (1997). Kierowanie kompetencjami. Bilanse doświadczeń zawodowych. Warszawa: Poltext.

Loewe, P., Dominiquini, J. (2006). Overcoming the barriers to effective innovation. Strategy \& Leadership, Vol. 34, No. 1, p. 24-31. Emerald Group Publishing Limited.

Roth, S. (2009). New for whom? Initial images from the social dimension of innovation. International Journal of Innovation and Sustainable Development, Vol. 4, No. 4, p. 231-252.

Schumpeter, J. A. (2002). The Economy as a Whole, Seventh Charter of the Theory of Economic Development. Industry and Innovation, Vol. 9, No. 1-2, p. 93-145.

Skrzypek, B. (2011). Biznes wsparty o innowacje, Nowoczesne zarządzanie, No. 2, p. 24-27.

Szczepańska-Woszczyn, K. (2014). SMEs managers - the need for competence. Acta Technologica Dubnicae, Vol. 1, Issue 1. Dubnica nad Váhom: Dubnický technologický inštitút.

Wojtowicz, A., Kozioł, L. (2012). Koncepcja aliansów wiedzy w procesie innowacji. Zeszyty Naukowe Małopolskiej Wyższej Szkoły Ekonomicznej w Tarnowie, Vol. 20, No. 1, p. 211-223. 


\section{INOVACINIA I PROCESA I SOCIALINEJEORGANIZACIJOS E R D V E J E}

KATARZYNA SZCZEPAŃSKA-WOSZCZYNA

Dabrowa Górnicza Verslo akademija (Lenkija)

Santrauka

Inovacija - tai ne tik ekonominis mechanizmas ar techninis procesas, tai visų pirma socialinis reiškinys, kai darbuotojų motyvacija ir dalyvavimas nulemia proceso sẻkmę. Todèl daugelis autorių akcentuoja socialinę inovacijų dimensiją. Straipsnyje apibendrinami tyrimų, kurie atlikti Lenkijos bendrovèse, rezultatai. Tyrimais siekta nustatyti švelniuosius inovacini procesą veikiančius veiksnius, tokius kaip žmogiškieji ištekliai, inovacinè atmosfera, inovacijoms palanki kultūra.

PAGRINDINIAI ŽODŽIAI: inovacijos, inovacijos procesas, žmogiškieji ištekliai, organizaciju vystymas.

JEL KLASIFIKACIJA: M5, O31 